Marquette University

e-Publications@Marquette

College of Nursing Faculty Research and

Publications

Nursing, College of

$5-4-2006$

\title{
Matching a Graduate Curriculum in Public/Community Health \\ Nursing to Practice Competencies: The Rush University \\ Experience
}

Susan M. Swider

Pamela F. Levin

Sarah Ailey

Susan Breakwell

Julia M. Cowell

See next page for additional authors

Follow this and additional works at: https://epublications.marquette.edu/nursing_fac

Part of the Nursing Commons 
Authors

Susan M. Swider, Pamela F. Levin, Sarah Ailey, Susan Breakwell, Julia M. Cowell, Diane McNaughton, and Marilyn O'Rourke 
Marquette University

e-Publications@Marquette

\section{Nursing Faculty Research and Publications/College of Nursing}

This paper is NOT THE PUBLISHED VERSION; but the author's final, peer-reviewed manuscript. The published version may be accessed by following the link in the citation below.

Public Health Nursing, Vol. 23, No. 2 (May 4, 2006): 190-195. DOI. This article is (C) Wiley and permission has been granted for this version to appear in e-Publications@Marquette. Wiley does not grant permission for this article to be further copied/distributed or hosted elsewhere without the express permission from Wiley.

\section{Matching a Graduate Curriculum in Public/Community Health Nursing to Practice Competencies: The Rush University Experience}

\section{Susan Swider}

Associate Professor, Rush University Medical Center, College of Nursing, Department of Community and Mental Health Nursing, Chicago, Illinois

Pamela Levin

Associate Professor, Rush University Medical Center, College of Nursing, Department of Community and Mental Health Nursing, Chicago, Illinois

Sarah Ailey

Assistant Professor, Rush University Medical Center, College of Nursing, Department of Community and Mental Health Nursing, Chicago, Illinois

Susan Breakwell

Assistant Professor, Rush University Medical Center, College of Nursing, Department of Community and Mental Health Nursing, Chicago, Illinois 


\section{Julia Cowell}

Professor and Department Chair, Rush University Medical Center, College of Nursing, Department of Community and Mental Health Nursing, Chicago, Illinois

\section{Diane McNaughton}

Assistant Professor, Rush University Medical Center, College of Nursing, Department of Community and Mental Health Nursing, Chicago, Illinois

\section{Marilyn O'Rourke}

Assistant Professor, Rush University Medical Center, College of Nursing, Department of Community and Mental Health Nursing, Chicago, Illinois

\section{Abstract}

ABSTRACT An evidence-based approach to Public/Community Health Nursing (P/CHN) requires that $\mathrm{P} / \mathrm{CHN}$ educators prepare practitioners with the relevant skills, attitudes, and knowledge. Such education should be competency-based and have measurable outcomes to demonstrate student preparation. In 2003, the Quad Council competencies were developed to be applied at two levels of public health nursing practice: the staff nurse/generalist role and the manager/specialist/consultant role. This paper describes a process for evaluation and revision of a graduate curriculum to prepare Advanced Practice Clinical Nurse Specialists (CNS) in P/CHN, to ensure that the educational program addresses and develops knowledge and proficiency in all relevant competencies. This paper documents the process of integrating the competencies throughout the $\mathrm{P} / \mathrm{CHN}$ graduate curriculum at varying levels, guiding students to achieve proficiency in each competency by the end of the program. Measurement of achievement in these competencies will be discussed, and examples provided. Advanced Practice Public Health Nurses educated via this competency-based approach will be prepared to sit for national certification as a CNS in Public/Community Health, and to assume leadership roles in public health nursing.

The movement in recent years within health care has been toward ensuring that all practices are based on scientific evidence of effectiveness and that health care practitioners have standardized, measurable competency achievement as evidence of their preparedness to practice (Foss, Janken, Langford, \& Patton, 2004; O'Neil \& Pew Health Professions Commission, 1998). Although the public health community has arrived at this position a few years behind the traditional, individual specialties of medicine and nursing, public health has recently developed its own set of professional competencies and is beginning to demand documentation of the competence of its practitioners. The public health competencies were developed to guide and direct practice and shape educational programs, as students need to be competent in the core areas for practice. Thus, curricula need to address these areas and use the competencies to measure students' achievements and readiness for practice.

Curricula of health professions are guided by standards that are related to licensing and accreditation. Historically that has been via licensure and certification exams. The competency movement begins to move educational programs into documenting skills and knowledge of students, as well as practitioners. Indeed, competency-based curricula are required to demonstrate knowledge and mastery in specific areas, in a broader way than what is demonstrated on a multiple-choice exam. Competency-based learning can be seen as part of a four-level pyramid, with individual characteristics 
and learning styles as the base, learned skills and knowledge as the next level, competencies as the merger of knowledge, skills, and abilities into useful tasks as the third level, and competency assessment via demonstration at the peak (National Postsecondary Education Cooperative, 2002). Academic programs are therefore encouraged to tie curricula to specific knowledge and skills, which cumulatively prepare the student for the licensing/certification exam and for practice in the field.

\section{History of Public/Community Health Nursing Competency Development}

The competencies for Public/Community Health Nursing (P/CHN) were developed by the Quad Council of Public Health Nursing Organizations. The Quad Council is an alliance of the four organizations that address public health nursing issues: the American Nurses' Association, the Association of Community Health Nursing Educators, the Public Health Nursing Section of the American Public Health Association, and the Association of State and Territorial Directors of Nursing.

To address the issues of core competencies for public health nursing practice, the Quad Council began by looking at the work of the Council on Linkages Between Academia and Public Health Practice (COL) and their "Core Competencies for Public Health Professionals" (2001). The COL work represents 10 years of development of competencies specific to public health across a variety of disciplines. The Core Competencies have been "cross walked" with the Essential Public Health Services to ensure that services fit with the competencies of public health professionals. The Core Competencies were designed to be used as a starting point for other disciplines to modify into discipline-specific public health competencies.

The COL divided the Core Competency list into the following eight domains: Analytic Assessment Skills, Basic Public Health Sciences Skills, Cultural Competency Skills, Communication Skills, Community Dimensions of Practice Skills, Financial Planning and Management Skills, Leadership and Systems Thinking Skills, and Policy Development/Program Planning Skills. The competencies within each domain are to be achieved at one of three levels-Awareness, Knowledge, and Proficiency-depending on the discipline and the position.

The Quad Council began looking at $\mathrm{P} / \mathrm{CHN}$ specific competencies by assuming that all nurses would meet basic baccalaureate prepared nursing competencies and that public health nurses would need to meet the public health-specific Core Competencies (2003). Furthermore, the Quad Council decided to address the Core Competencies and determine their application to two levels of public health nursing practice: the staff nurse/generalist role (baccalaureate prepared) and the manager/specialist/consultant role (master's prepared). The Quad Council recognized and maintained the COL's continuum of competency achievement, of awareness to knowledge to proficiency, depending on the nursing role. After considering comments from public health nurses, the Quad Council adopted and disseminated the final version in 2003 (Quad Council, 2003). The 68 competencies arranged in eight domains are intended to reflect the standard for public health nursing practice, not necessarily what is occurring in practice today. In any practice setting the job descriptions may reflect components from each level, depending on the agency's structure, size, leadership, and services. 


\section{Graduate Education in $\mathrm{P} / \mathrm{CHN}$ at Rush University}

Rush University was created in 1972 as a health professions university, consisting of the Colleges of Nursing, Medicine, Health Professions, as well as the Graduate College. The nursing program, however, dates back to 1885 with several hospital-based diploma programs. Since the formation of Rush University College of Nursing, 4,700 students have graduated with a Bachelor of Science in Nursing (B.S.N.), Master of Science in Nursing (M.S.N.), Doctor of Nursing Practice (D.N.P.), or Doctor of Nursing Science (D.N.Sc.) degree. The M.S.N. options cover a wide variety of clinical specialties, including $\mathrm{P} / \mathrm{CHN}$.

The College of Nursing is rich in faculty with expertise in various $\mathrm{P} / \mathrm{CHN}$ roles. The $\mathrm{P} / \mathrm{CHN}$ faculty members meet regularly as a group to discuss challenges and issues in their work in education, practice, and research. Recently, faculty discussed the need to clarify the role of the advanced practice nurse in $\mathrm{P} / \mathrm{CHN}$. Part of the process of "charting" the $\mathrm{P} / \mathrm{CHN}$ role involved certification and credentialing, as measured by passage of the certification exam for specialists in $\mathrm{P} / \mathrm{CHN}$. Preparation for this exam in most clinical areas is tied to professional competencies. The use of practice competencies in $\mathrm{P} / \mathrm{CHN}$ education has not been published. In keeping with the Rush tradition of clinical excellence, faculty resolved that the $\mathrm{P} / \mathrm{CHN}$ graduate program would meet certification standards in terms of clinical practica hours, as well as meeting professional practice competencies. Thus, the faculty decided to evaluate the curriculum in terms of the Quad Council Competencies for specialists in the field and then to revise the curriculum to ensure that all graduates would demonstrate the requisite skill level.

\section{Competency Assessment and Program Modification Process}

The plan to assess the current P/CHN MSN curriculum using the Quad Council Competencies was enhanced by the overall evaluation plan in place in the College of Nursing, the CIPP (context, inputs, processes, and products) model. The CIPP model, based on Stufflebeam's work (Madaus, Scriven, \& Stufflebeam, 1991), includes evaluation of the program's context, inputs, processes, and products. Following the CIPP model, the college's well-established evaluation plan focuses on the continuous assessment of processes and outcomes and emphasizes the importance of accountability. Quantitative and qualitative data are collected using multiple methods and sources, which include students, graduates/alumni, faculty, preceptors, Advisory Committee members, and employers. When a problem emerges during analysis of evaluation data, those responsible for resolving the problem generate an action plan for improvement. Program faculty make changes in context (resources), inputs, and processes (activities) based on evidence from the data, and results are monitored through additional evaluations.

During the past year, the Graduate Curriculum Committee of the College of Nursing instituted a biennial review process for all graduate-level courses to document and monitor currency and curricular fit. As part of this review, each course would be assessed for how it addressed the relevant competencies, those of the American Association of Colleges of Nursing Master's Essentials, the National Organization of Nurse Practitioner Faculties Core, and relevant specialty competencies. Thus all faculty were now required to complete a course review every 2 years for any graduate course they were involved in leading and/or developing. 
The $\mathrm{P} / \mathrm{CHN}$ faculty accelerated the process by conducting a review of all $\mathrm{P} / \mathrm{CHN}$ specialty courses and documenting how the Quad Council Competencies were addressed. Faculty assessed whether competencies were addressed at the Awareness, Knowledge, or Proficiency level. For the highest level achieved, faculty documented which course objective addressed the competency and how achievement was measured. This first level of review involved the specialty core courses and took faculty 6 months to complete and reach consensus. The results of the course review were documented in a table listing the Quad Council Competencies, and levels achieved with corresponding measurement (Table 1).

Table 1. Public Health/Community Health Nurse Competency Example

\begin{tabular}{|c|c|c|c|c|}
\hline $\begin{array}{l}\text { Domain 4: Cultural } \\
\text { Competency Skills }\end{array}$ & $\begin{array}{l}\text { Level of } \\
\text { Achievement } \\
\text { by Course Title } \\
\end{array}$ & & & Measurement \\
\hline & Awareness & Knowledge & Proficiency & \\
\hline $\begin{array}{l}\text { Utilizes appropriate } \\
\text { methods for interacting } \\
\text { sensitively, effectively, and } \\
\text { professionally with persons } \\
\text { from diverse cultural, } \\
\text { socioeconomic, } \\
\text { educational, racial, ethnic, } \\
\text { and professional } \\
\text { backgrounds, and persons } \\
\text { of all ages and lifestyle } \\
\text { preferences }\end{array}$ & $\begin{array}{l}\text { Health } \\
\text { promotion in } \\
\text { diverse } \\
\text { populations }\end{array}$ & $\begin{array}{l}\text { Population } \\
\text { health } \\
\text { assessment } \\
\text { and program } \\
\text { planning }\end{array}$ & $\begin{array}{l}\text { Program } \\
\text { implementation } \\
\text { and evaluation } \\
(3-5) \\
\text { MSN Capstone } \\
(2)\end{array}$ & $\begin{array}{l}\text { Program plan } \\
\text { presentation, } \\
\text { clinical log, } \\
\text { preceptor } \\
\text { evaluation } \\
\text { Capstone paper }\end{array}$ \\
\hline $\begin{array}{l}\text { Identifies the role of } \\
\text { cultural, social, and } \\
\text { behavioral factors in } \\
\text { determining the delivery of } \\
\text { public health services }\end{array}$ & $\begin{array}{l}\text { Health } \\
\text { promotion in } \\
\text { diverse } \\
\text { populations }\end{array}$ & $\begin{array}{l}\text { Population } \\
\text { health } \\
\text { assessment } \\
\text { and program } \\
\text { planning }\end{array}$ & $\begin{array}{l}\text { Program } \\
\text { implementation } \\
\text { and evaluation } \\
(3-5) \\
\text { MSN Capstone } \\
(2)\end{array}$ & $\begin{array}{l}\text { Program plan } \\
\text { paper, clinical } \\
\text { log, preceptor } \\
\text { evaluation } \\
\text { Capstone paper }\end{array}$ \\
\hline $\begin{array}{l}\text { Develops and adapts } \\
\text { approaches to problems } \\
\text { that take into account } \\
\text { cultural differences }\end{array}$ & $\begin{array}{l}\text { Theoretical } \\
\text { foundations } \\
\text { for advanced } \\
\text { practice }\end{array}$ & $\begin{array}{l}\text { Population } \\
\text { health } \\
\text { assessment } \\
\text { and program } \\
\text { planning }\end{array}$ & $\begin{array}{l}\text { Program } \\
\text { implementation } \\
\text { and evaluation } \\
(2-6) \\
\text { MSN Capstone } \\
(2)\end{array}$ & $\begin{array}{l}\text { Program plan } \\
\text { paper, preceptor } \\
\text { evaluation } \\
\text { Capstone paper }\end{array}$ \\
\hline $\begin{array}{l}\text { Attitudes: Understands the } \\
\text { dynamic forces contributing } \\
\text { to cultural diversity }\end{array}$ & $\begin{array}{l}\text { Health } \\
\text { promotion in } \\
\text { diverse } \\
\text { populations }\end{array}$ & $\begin{array}{l}\text { Population } \\
\text { health } \\
\text { assessment } \\
\text { and program } \\
\text { planning }\end{array}$ & $\begin{array}{l}\text { Program } \\
\text { implementation } \\
\text { and evaluation } \\
(3-5) \\
\text { MSN Capstone } \\
(2)\end{array}$ & $\begin{array}{l}\text { Program plan } \\
\text { presentation, } \\
\text { clinical log, } \\
\text { preceptor } \\
\text { evaluation } \\
\text { Capstone paper }\end{array}$ \\
\hline
\end{tabular}




\begin{tabular}{|l|l|l|l|l|}
\hline $\begin{array}{l}\text { Attitudes: Understands the } \\
\text { importance of a diverse } \\
\text { public health workforce }\end{array}$ & $\begin{array}{l}\text { Health } \\
\text { promotion in } \\
\text { diverse } \\
\text { populations }\end{array}$ & $\begin{array}{l}\text { Population } \\
\text { health } \\
\text { assessment } \\
\text { and program } \\
\text { planning }\end{array}$ & $\begin{array}{l}\text { Program } \\
\text { implementation } \\
\text { and evaluation } \\
(2-4)\end{array}$ & $\begin{array}{l}\text { Clinical log, } \\
\text { preceptor } \\
\text { evaluation }\end{array}$ \\
\hline
\end{tabular}

- Note : Awareness is the basic level of mastery of the competency. Individuals may be able to identify the concept or skill but have limited ability to perform the skill. Knowledge is the intermediate level of mastery of the competency. Individuals are able to apply and describe the skill. Proficiency is the advanced level of mastery of the competency. Individuals are able to synthesize, critique, or teach the skill.

- a Related course objectives are in parentheses.

The second step in the review process was at the domain level. Faculty members took responsibility for reviewing the courses for one of the eight domains of the Quad Council Competencies. Each faculty member reviewed syllabi for each course, using the initial table, and cross-checked the competencies addressed by the course across the selected domain. Faculty members brought the domain review to the larger P/CHN faculty group to discuss any differences from the first stage review; consensus was reached about how each competency was addressed, at what level, and with what documentation/measurement. Additionally, the review was designed to assure that the plan of study advanced the student through the levels of competency achievement in a logical manner. The domain review served as a check on the consistency of the earlier course review process; the domain review took an additional 5 months to complete.

The last step in this review process was to examine each competency for gaps in the curriculum and determine how best to address the gaps. To date, the gaps found are primarily in the area of Leadership and Systems Thinking. Most of the gaps will be addressed via revisions in the course objectives for the clinical practicum hours in the program. The Rush program requires students to have 12 quarter hours of practicum (360 clock hours) and $2 \mathrm{hr}$ of residency ( 240 clock hours) for a total of 600 clock hours of practicum experience. The practicum requirement exceeds the certification requirement for the Clinical Nurse Specialist (CNS) in $\mathrm{P} / \mathrm{CHN}$, which is 500 clock hours. Thus, Rush students have ample opportunities to hone their clinical skills and achieve the requisite proficiency in the relevant competency areas. Faculty are currently in the process of developing free-standing content modules, which address any competency areas requiring further study to achieve the appropriate level, and which will accompany the students' clinical hours.

The steps that remain include a review by $\mathrm{P} / \mathrm{CHN}$ practice experts who are members of the program Advisory Council. In addition, ongoing review of courses will help to ensure that courses remain competency based and that curricular changes related to the competencies are measurable. At Rush, this will be performed via the biennial review process developed and implemented on a college-wide basis. In fact, this ongoing review will have the side benefit of educating the rest of the nursing faculty in the $\mathrm{P} / \mathrm{CHN}$ competencies for $\mathrm{P} / \mathrm{CHN}$ Clinical Specialists. 


\section{Measuring Competencies in Student Outcomes}

There have been two overriding challenges in the review work to date. The first has been the concept of levels of competency, defined as Awareness, Knowledge, and Proficiency. The definitions of the levels in the Quad Council (2003, p. 1) document are as follows:

1. Awareness : Basic level of mastery of the competency. Individuals may be able to identify the concept or skill but have limited ability to perform the skill.

2. Knowledge : Intermediate level of mastery of the competency. Individuals are able to apply and describe the skill.

3. Proficiency : Advanced level of mastery of the competency. Individuals are able to synthesize, critique or teach the skill.

The Rush P/CHN faculty struggled to differentiate Knowledge from Proficiency and to ensure that student work would indeed assure Proficiency by the end of the program. The ability to synthesize and critique a skill are hallmarks of specialty education at the graduate level. However, the ability to teach a skill often requires a higher level of comfort and expertise, so that one can break down the skill or concept into teachable parts. The faculty will continue to assess the curricula to ensure that Proficiency is met when applicable.

This leads to the second challenge, which is measuring Proficiency. In the review and revision of the graduate curriculum to address these competencies, the faculty did not address measurement at the levels of Awareness and Knowledge when Proficiency was the level to be achieved; measurement of Awareness and Knowledge is commonly carried out in academic settings. Faculty did think, however, that if one were to document achievement of proficiency, one needed to focus on appropriate measurement of each competency.

The measures of Proficiency the faculty used included population assessment and program development projects, policy analyses, budget development and management, as well as other formal exercises to document achievement. However, some of the competencies are process oriented and a final product as a measure is not the most appropriate documentation of achievement. Examples include: Domain 3 Communication Skills, 3.3 Advocates for public health program and resources ; or Domain 7 Financial Planning and Management Skills, 7.7 Applies basic human relations skills to the management of organizations, motivation of personnel, and resolution of conflicts. Proficiency in the aforementioned competencies is best measured via observation of the individual in practice over time. Thus, faculty determined that some competencies are best evaluated by the student's clinical preceptors. Because $\mathrm{P} / \mathrm{CHN}$ students can be in several diverse settings for their practicum, preceptors may differ in their role and judgment of student performance. Faculty realize the need to develop a user-friendly tool to standardize preceptor evaluations as much as possible across individual preceptors and settings. The largest challenge going forward, therefore, is implementing a competency-based curriculum in a way that student achievement and learning can be reliably and validly measured across preceptors and settings. 


\section{Conclusions}

In conducting a cost-benefit estimation of the evaluation process to ensure that graduates of the advanced practice nursing program in $\mathrm{P} / \mathrm{CHN}$ met specialty competencies, the faculty believe that the process was of overall benefit to the program. The benefits include the fact that the resulting curriculum has enhanced relevance to clinical practice. In addition, the evaluation process forced faculty to gain expertise in the competencies, and to consider the competencies in relation to teaching/learning principles.

The cost of this process, however, was that it was time and labor intensive. The process documented here, of a year's duration, was actually discussed and planned for a year preceding the implementation. Resulting curricular revisions will take another 6 months. The evaluation work was also somewhat tedious, and keeping faculty motivated and on track, in the face of conflicting demands on their time, was challenging. However, because of the College of Nursing's ongoing evaluation matrix and the biennial course review mechanism, the work done with the curriculum will be maintained with much less effort than required for this initial evaluation.

That said, the authors would recommend this process to other educational programs. In balance, the authors believe that it was cost effective because of the value added to the curriculum. Other schools choosing to replicate this work in their curricula benefit in terms of developing competency-based curricula, enhanced faculty understanding of the $\mathrm{P} / \mathrm{CHN}$ competencies, and enhanced clinical relevance of their curricula. Ultimately these efforts strengthen the link between education and practice.

Advanced practice nurses in $\mathrm{P} / \mathrm{CHN}$ graduate proficient in the competencies required for their practice, which serves to enhance their work, and thus the health of the public.

\section{Acknowledgments}

This work was conducted with the support of HRSA Grant D09HP03144.

\section{References}

Council on Linkages Between Academia and Public Health Practice. (2001). Core competencies for public health professionals . Retrieved May 26, 2005, from http://www.phf.org/Link.htm

Foss, G. F., Janken, J. K., Langford, D. R., \& Patton, M. M. (2004). Using professional specialty competencies to guide course development. Journal of Nursing Education, 43, 368- 375.

Madaus, G. F., Scriven, M., \& Stufflebeam, D. L. (1991). Evaluation models. Boston: Kluwer-Nijhoff.

National Postsecondary Education Cooperative. (2002). Defining and assessing learning: Exploring competency-based initiatives . Retrieved May 26, 2005, from http://nces.ed.gov/pubs2002/2002159.pdf

O'Neil, E. H., \& Pew Health Professions Commission. (1998). Recreating health professional practice for a new century. Retrieved May 26, 2005, from http://www.futurehealth.ucsf.edu/compubs.html

Quad Council of Public Health Nursing Organizations. (2003). Quad Council Public Health Nursing Competencies . Retrieved May 26, 2005, from http://www.uncc.edu/achne 